\title{
Semiotics of Power and Dictatorship in Ngũgĩ wa Thiong'o's Later Novels
}

\author{
Yémalo, C. AMOUSSOU (Corresponding author) \\ Department of English Studies, Faculty of Arts and Humanities (F.L.A.S.H), University of Abomey-Calavi (UAC), Benin \\ E-mail: cayemal@yahoo.com
}

Doi:10.7575/aiac.alls.v.7n.5p.208

URL: http://dx.doi.org/10.7575/aiac.alls.v.7n.5p.208
Received: 23/06/2016

Accepted: $30 / 08 / 2016$

\begin{abstract}
This paper explores the different uses of symbols to express power and interpersonal relationship in Ngũgĩ's bulkiest novel Wizard of the Crow (2006), with a few illustrations from Matigari (1987). It draws on the semiotic approach and identifies about a hundred discourse strings in which signs are used to express tenor between characters. In the main, supernatural, faunal and floral symbols are found to be main vehicles of power, though many other such avenues as 'vocations', 'social and gender-related symbols' and 'biblical characterisation and numerology', etc are unexplored here for space constraints. Before the analysis, it is deemed necessary to overview the theoretical background to the study in which relevant concepts have been clarified. It has been concluded that there is no other work in which power is so much expressed through the explored devices as in Wizard of the Crow.
\end{abstract}

Keywords: tenor, symbol, index, proverb, modality metaphor, modaliser/ weakener, modulator/strengthener

\section{Introduction}

It is a known fact that the Kenyan writer Ngũgĩ wa Thiong'o uses animal symbols in character naming in his novels. In his Petals of Blood (1977) and Devil on the Cross (1982), such characters as Chui (a leopard), Nderi (a vulture/an eagle), Kimeria (a hawk), Wangari (a leopardess), Kihaahu (a king-stock, a mosquito), Kĩmeedeeri (an ox-pecker, a maggot), Fathog (a big pig), Gītutu (a big jigger, a pregnant spider), Ndītīka (a pregnant spider, he who carries a heavy burden) and Gitahi (a scooper, a jigger, a louse, a flea, a bedbug, a mistletoe), etc are named after and likened to animals to reflect their ideological inclinations (Amoussou, 2011; Koussouhon \& Amoussou; 2015b, Ndïgïrïgï, 2015). Yet, in neither of these novels has the writer made so much use of such symbols as to reveal tenor, i.e., the relations of power and solidarity between the different characters (Halliday \& Matthiessen, 2004; Eggins, 2004) as in his later ones. Though many vehicles of power can be found in the novels, the current study focuses on the uses of supernatural, faunal and floral signs to express tenor in Wizard of the Crow (2006) and in Matigari (1987). Indeed, an insight into these signs has helped the researcher to reveal much about the interpersonal relationship between the characters, viz., the Ruler, Machokali (minister of Foreign Affairs), Silver Sikiokuu (Minister of State), John Kaniũrũ (a youth-winger become Minister of Defense), Big Ben Mambo (Minister of Information), Titus Tajirika (a business tycoon become a Ruler's advisor, a Central Bank Governor, a Minister and an Emperor), Kamïtï or Wizard of the Crow (WOC),Nyawïra, the leader of the Movement for the Voice of the People (MVP), Wangahũ (Nyawïra's father), and three security men: A. G., Peter Kahiga and Elijah Njoya. The work is divided into three sections: theoretical background, analysis of power symbolism and recapitulation of the findings.

\section{Theoretical Background: Semiotics, symbol, icon, index and Power}

The term 'semiotics' is broadly defined as being "concerned with everything that can be taken as a sign" (Eco, 1976:7). While semioticians of the Saussurean school argue that 'semiotics' and 'semantics' have a common concern with the meaning of signs, and specify that "semantics focuses on what words mean while semiotics is concerned with how signs mean" (Sturrock, 1986:22), those of the Peircean school opine that it embraces such other branches of linguistics as: 'semantics' -'the relationship of signs to what they stand for', 'syntax' -the formal or structural relations between signs' and 'pragmatics' - 'the relation of signs to interpreters' (Morris, 1970:6-7). It involves the study not only of what is ordinarily known as 'signs', but also of anything that is used to stand for something else. In this case, 'a sign' can take the form of a word, an image, a sound, a gesture, an object, an odor, a flavor etc. (Chandler, 2001:2) but these forms have no intrinsic meaning and become signs only when they are invested with meaning (Peirce, 1958:172).

There is a clash between the Saussurean scholars' use of the term 'sign/symbol' and the Peircean ones'. While Saussure ([1916] 1983:67) sees the 'the sign' as "the whole that results from the association of the signifier with the signified and the relationship between the two as the "signification", Peirce (1958: 302) regards it as "something which stands to somebody for something in some respect or capacity" (p.228) and goes as far as to declare that "every thought is a sign" (p.283). In addition, Saussure distinguishes between 'arbitrary symbolism' and 'rational symbolism', insisting that the term 'symbol' is used in everyday speech to express a rational, not an arbitrary, relationship: "such signs are never wholly arbitrary. They are not empty configurations. They show at least a vestige of natural connection between the 
signifier and the signified" $(1983: 68,73)$. As for Peirce, he sees 'a symbol' as "a sign which refers to the object that it denotes by virtue of a law, usually an association of general ideas, which operates to cause the symbol to be interpreted as referring to the object" (1958: 249). He insists that "the symbol is connected with its object by virtue of the idea of the symbol-using animal, without which no such connection would exist" (307), and that "it would lose the character which renders it a sign if there is no interpretant" (304). For Peirce, thus, the role of the interpreter must be accounted for in a study of symbols: "Nothing is a sign unless it is interpreted as a sign" (1958:172). Leach (1970:43) puts it this way: "In order to be able to operate with symbols it is necessary first of all to be able to distinguish between the sign and the thing it signifies." Similarly, Sless (1986: 6) opines that "statements about users, signs or referents can never be made in isolation from each other. A statement about one always contains implications about the other two"

It is theorized that a sign has three modes of expression: icon/iconic, index/indexical and symbol/symbolic (Peirce, 1958; Chandler, 2001). These are summed up in table 1.

Table 1. Modes of Expression of a Sign; adapted from Chandler, 2001: 11-12

\begin{tabular}{ll}
\hline $\begin{array}{l}\text { Modes of expression of a } \\
\text { sign }\end{array}$ & Definitions \& examples \\
\hline symbol/symbolic & $\begin{array}{l}\text { a mode in which the signifier does not resemble the signified but which is fundamentally } \\
\text { arbitrary or purely conventional, so that the relationship must be learnt (e. g.: language, } \\
\text { graphemes, words, numbers, Morse code, traffic lights, national flags, metaphor, etc). }\end{array}$ \\
\hline index/indexical & $\begin{array}{l}\text { a mode in which the signifier is not arbitrary but is directly connected in some way } \\
\text { (physically or causally) to the signified through observation or inference (e. g.: natural } \\
\text { signs: smoke, thunder, footprints, etc; photographs, pointers, signposts, medical } \\
\text { symptoms, recorded voices, catchphrases, clocks, etc). }\end{array}$ \\
\hline icon/iconic & $\begin{array}{l}\text { a mode in which the signifier is perceived as resembling or imitating the signified } \\
\text { recognizably by looking/sounding/feeling/tasting/smelling like it (e. g.: a portrait, a } \\
\text { cartoon, onomatopoeia, a simile, etc). }\end{array}$ \\
\hline
\end{tabular}

Even then, there is some difficulty to clearly tell between 'an icon', 'an index', and 'a symbol'. While Peirce (1958) argues that "every picture is an icon" (p.279), Langer (1951) sees it as a symbol: "the picture is essentially a symbol, not a duplicate, of what it represents" (p. 67). As for Hawkes (1977), he notes that the three modes "co-exist in the form of a hierarchy in which one of them will inevitably have (context-determined) dominance over the other two" (p.129). In fact, the same signifier may be used iconically in one context and symbolically in another. For instance, a photograph of a woman may stand for a broad category of 'women' (the type/symbolic) or may more specifically represent only the particular woman depicted (the individual/iconic). What is more, classification depends on the reader/interpreter: a sign may be treated as iconic by one person but as indexical by a another and as symbolic by a third: "When we speak of an icon, an index or a symbol, we are not referring to objective qualities of the sign itself, but to the viewer's experience of the sign" (Grayson, 1998: 35). There may even be a diachronic shift in both the mode and its interpretation over time: what a 504 Peugeot meant for people 20 or 30 years ago is not what it does today. As Culler (1975) puts it: "In one sense a Rolls-Royce is an index of wealth in that one must be wealthy in order to purchase one, but it has been made a conventional sign of wealth by social change" (p.17). For the controversy among the three forms, the term 'symbol' is in this paper used when confusion exists, though they are indifferently so at times.

The notion of power also needs briefing. This term has a hyponym-relationship with superordinate term 'tenor', i., e., the relationship of power, solidarity, familiarity and affective involvement between participants or the degree of authority, confidence, certainty, objectivity with which a story is told (Fowler, 1986; Eggins, 2004). It is also used to describe the change-effect of discourse on listeners/readers (Fairclough, 2003; 2014). In semiotics, tenor operates mainly through 'modality', i.e., the reality status accorded to or claimed by a sign, a text or genre, as Hodge and Kress (1988) declare: "Modality refers to the status, authority and reliability of a message, to its ontological status, or to its value as truth or fact" (p.124).

Fairclough (2003) sees modality as a resource for expressing personality, character, identity, and tenor:

Modality is important in the texturing of identities, both personal (personalities) and social, in the sense that what you commit yourself to is a significant part of what you are -so modality choices in texts can be seen as part of the process of texturing self-identity....How one represents the world, to what one commits oneself, e.g., one's degree of commitment to truth, is part of how one identifies oneself, necessarily in relation to others with whom one is interacting (p.166).

The grammar of modality has two major components: 'modulation' and 'modalisation'. While the former has to do with the use of modal verbs and locutions like 'can, may, might, perhaps, maybe, as though, seemed, looked, appeared, etc', known as 'modalisers'/ ' weakeners', to mark subjectivity or caution or partiality or probability, the latter is about the expression of confidence, power, obligation, necessity, and truth-hood through such other modals as 'must, need, should, ought to, had better, can't, etc', known as modulators/strengtheners', and proverbial sentences (Fowler, 1986: 
132, 137). In addition, Halliday and Matthiessen (2004: 616-635) argue that modality is metaphorically represented when speakers variously express their opinions in such ways as to disseminate the fact that they are expressing their own opinions. This is generally achieved through expressions like "it is obvious that, it stands to reason that, nobody can deny that, it is particularly difficult to avoid the conclusion that, there can be no doubt that, the impartial spectator will surely agree that, most people would agree that, etc". The next section systematically identifies and analyses the discourse strings in which signs are used to express power and dictatorship in the novels under investigation.

\section{Analysis of Power Semiotics in the Selected Novels}

This section first analyses the use of supernatural signs/forces to express power (sub-section 3.1), then, that of faunal and floral symbols for the same goal (subsection 3.2) and finally recapitulates the findings of both under 3.3.

\subsection{Analysis of Power-Expressive Functions of Supernatural Signs}

Characters' identification with natural signs is one of the tenor devices in WOC. The quote below, for instance, shows how the Ruler's arrival in a cathedral triggers such a strong earthquake that the bishop uses sacred objects to expiate the power struggling to be free:

(1) Though details conflict, all agree that as soon as the Ruler set foot inside the cathedral, the walls shook as if moved by an earth tremor. Crosses on the walls, people's clothes, or pieces of paper danced strangely, as if struggling to flee. And when Bishop Tireless Kanogori placed on the altar a small Bible he had been holding in his hands, the altar shook and the Bible fell to the ground.......He re-emerged holding a very big Bible in his right hand and a huge cross in his left, both hands outstretched towards the Ruler. The Bishop's lips were moving as if making an incantation, but nobody could catch his words and so were unable to repeat them afterward. Then the whole congregation heard the sound of something crashing through a window, breaking the glass into seven pieces, and then suddenly, all the shaking walls and dancing crosses became still and the whole cathedral was embraced in silence and peace....(pp.27-8, emphasis added)

The return of silence and peace to the parish after the expulsion of the power gives the impression of the Ruler as a daemon-possessed person, the whole ritual looking like an exorcism similar to Christ's casting away of demons (Mark 3: 23-30; Matthew 12: 26-32). Here modality is expressed through 03 metaphors of modality - 'all agree that, nobody could, the whole congregation heard' (Halliday \& Matthiessen, 2004: 616-635)- and 03 modalisers - 'as if, as if, as if' (Fowler, 1986:132). The Ruler's visits to other such places cause the same signs and the preachers have to wield a Bible/Quran and a cross/rosary to drive the force out:

(2) It is said that the Ruler did thereafter attend a few other services in other churches with similar results: in all cases at least one glass window is broken was shattered into seven pieces by whatever force the cross-and-Bible-wielding priests had driven out (p.28)

(3) Those in attendance say they felt something like a wind whirl through the air and the next minute they heard the iron bars of one of the windows creak and they saw some of them bend outwards as if someone were pushing the bars to set himself free. Brandishing the Quran and the rosary at the window, the imam shouted something like Satan, and lo and behold the creaking stopped abruptly" (p.29)

The decision of the mosque's ruling council to let the bent "iron bar like that, a witness to the victory of the Holy Quran over the wiles of Satan, even when disguised in the modern fineries of early glory" (p.29) contains clues that Satan here is human: the phrase 'modern fineries of earth glory' refers to the Ruler's Europe-sewn suits (p. 19) and the reference 'himself' to the indefinite pronoun 'someone' can be a way of pointing to both the humanity and masculinity of 'Satan'. Moreover, the breaking of the windows into 'seven' indirectly points to the Ruler, this being his sacred number (p. 12). In (2), and (3), there are 03 modality metaphors-'it is said that, those in attendance say, they felt...heard....saw' (Halliday \& Matthiessen, 2004: 616-635) and 03 modalisers: like, as if, like' (Fowler, 1986: 132). The softening effect of these weakeners is somehow balanced up by the emphatic 'did' which serves to introduce them. The runaway of Satan in the presence of the cross/rosary, symbol of Christ/Mohamed, and of the Bible/Quran, symbol of the Word of God, not only confirms the power of these holy media on the Devil but also puts the two faiths on equal footing in the fight against Satan.

The Snake/Serpent/Devil symbol comes up again in the beggars' chant against the Marching-to-Heaven plan: (4). “The March to Heaven Is Led by Dangerous Snakes. This last slogan was chanted over and over” (p.74). The plural form 'Snakes' extends the symbol beyond the Ruler to include such key figures in the scheme as Machokali, Tajirika and Kaniũrũ. The Ruler's description after the explosion also evokes that of a snake as he is seen as (5) "a long-necked something with a tiny head and a forked tongue" (p.708). The fact that, in their search for Satan, the Christian Soldiers' sight of the Ruler's sculpture evokes the image of donkey-rider in imitation of Jesus, with the equation of this rider with a Devil-Worshipper, confirms the demonic stigma attached to the Ruler:

(6) 'Look,' one of the soldiers shouted, pointing a finger at something across the street, a sculpture of the Ruler on horseback. The Soldiers of Christ quickly read his mind, for the bronze sculpture reminded them of the not so distant spectacle of the Devil worshipper riding a donkey in imitation of Christ, an act of sacrilege for sure. But why did the vision appear to them at this moment? In their hour of need? They 
recalled that God had forbidden the children of Israel to make graven images Why? Because Satan could easily hide in a sculpted image. (p.35).

There appears to be a double indexical link, first between 'the Ruler's bronze sculpture' and 'the Devil Worshipper' and between 'his sculpted image' and 'Satan', who is no other entity than 'the Snake'/'the Viper'/the Prince of Darkness' (p.89). In (7), the snake symbol, drawing on the Moses-Pharaoh clash (Exodus 7: 11-12), is used to project victory of autocracy over democracy, through the reversal of Moses' triumph over Pharaoh:

(7) He, the Ruler, would outsnake their plastic terrorist snakes with real ones. In biblical times, it was the Mosaic snakes that swallowed the Pharaonic ones. Today in Aburĩria, it is the Pharaonic snakes that will swallow all of you who think that you are the new Moses (p.25) (emphasis added).

The Ruler's identification with the Pharaoh, an enemy of the children of Israel and the M.V.P.'s equation with 'Moses', an emblem of freedom, show the clash between dictatorship and democracy. The snake/devil stigma attached to the Ruler is crowned by the popular snake-song after his attempt to throw his club at those he sees as 'self-styled Moseses': (8) "The pot I made is broken -little did I know that freedom-would bear a viper and a devil" (p.25). Here, 'the pot' symbolises 'the nation' while 'a viper/a devil', the Ruler. Moreover, the Christian Soldiers' hardship to spot Satan within the Ruler's sculptures and premises is likened to that met by the Magi in search of the Child Jesus, which makes an indirect hint to Herod the Sanguinary (Matthew 2: 1-12):

(9) "Like the wise men from the East who encountered numerous difficulties on their way to see the infant in the manger, the soldiers of Christ endured many hardships in their search for Satan inside the many buildings in Eldares (p.36).

The Ruler is not the only figure to be related to supernatural forces. While Tajirika just wants a magic to prevent his property from being (10) "blown away by the wind" (p.330), here is what a business tycoon tells the wizard:

(11) Do you know the story of the great battle between the Sun and Wind over who could make Man take off his coat? Wind made Man only cling more to his possession. Sun made him surrender it willingly. Wizard of the Crow, make my enemies the Wind. Make me the Sun" (p.150, my emphasis).

As the Sun-Wind symbols show, this man is after the power to dispossess others. He even seems to be representative of the elite who reject science and reason when they are in search of the occult. For instance, when the WOC tells him that 'divination is a science' (p.151), the man's insistence on his want for 'the pure play of occult powers...magic, not science" (p.151), prompts Nyawïra to observe and generalize this habit to the ruling elite:

(12) Nyawïra could hardly believe her ears. If she had heard an account of what she herself had heard, she would, almost certainly, have dismissed it as a lie: the rich and the powerful denouncing scientific reason in favor of illogical mumbo jumbo. And to know that these men belong to the same class as the leaders of new nations? What did the future of the country hold with these men at the helm? (p.151, my emphasis).

It must be noticed that such items as 'the rich, the powerful, these men, new nations' are strangely pluralized. In the context, this pluralisation helps to symbolically generalise the search of occult powers to the whole ruling African elite. Interestingly, Kamiiti, for the discomfort of two security men come to consult him, observes:

(13) He had often seen a similar unease, especially among religious zealots, educated professionals, and high-ranking civil servants who on the surface pretended not to believe in the occult. A priest who used to denounce sorcery every Sunday once came to him at dawn, only to bump into one of his parishioners at the shrine. Each had proceeded to claim the wizard as a relative and offered this as the reason of their visit. Both had excused themselves and said that they would come another time (p.368).

The sun's power is accounted for by its fire-and-light producing capacity that has led people to worship it as 'a god', as Kamïti tells Nyawïra: (14) "Long ago, my ancestors, the hunters, believed the sun was our god because it was the source of fire and light' (p.211). While It must be pointed out that the belief in the 'sun god' is universal, the name 'Sunday' coming from that belief, it must equally be noted that 'the Ruler=the Country' equation is said to be (15) 'as obvious as the fact that the sun is the source of heat and light' (p. 162) and thus reinforces his association with power. When the students invited to a Kaniũrũ-chaired seminar delay coming while the press eagerly expects the Ruler to open the event, Kaniũrũ uses the proverb (16) "The sun never waits for anybody, not even a king, and he was not yet a king" (p.573) to point to the sun's power over a king's one, thus equating the Ruler to 'the sun' and himself, somehow, to 'a king'. When Tajirika suggests turning the country into 'corporate colony' (p. 746), the Ruler stresses the need for the West to deal with him in saying: (17) "I am their only sun here, and they will have to deal with the sun as is" (p.747). 
The sound of the Ruler's landing plane back from America is likened to that of an earthquake, thunder, and a volcanic disturbance, just as is the tremor of his shaking hand and body, as in (18), (19) and (20):

(18) "It was the sound of the plane landing that announced the return of the Ruler from his famous visit to America, for it was louder than thunder. People said that only His Mightiness could produce thunder without lightening and rain" (p. 517, emphasis mine)

(19) “'What? What did you say?' the Ruler was asking. His face darkened and his hands shook, sending $\boldsymbol{a}$ tremor through his whole body. The entire State House, the whole country, and the whole people, feeling the earthquake, recalled the seismic disturbance during the Ruler's return from America (p.548, my emphasis).

(20) He would sob tearlessly, with ever greater frustration and bitterness, his shoulders heaving and his body shaking, as did not only the building but the entire country, some people mistaking this effect for an earthquake or volcanic eruption somewhere"(p.518, my emphasis).

While these supernatural signs help to point to the Ruler's anger on return from his disastrous New-York trip, the overall context hints at a similar real-life trip, 'the 1990 Washington Debacle' by President Moi (Kamau, 2012: 2; Njuru, 2016: 4). Indeed, the failure of this trip, added to instability at home, seems to trigger so much anger that consumes the Ruler's heart and gives rise to a local saying: (21) "Ire is more corrosive than fire for it once eroded the soul of a Ruler" (p.3). These indexes thus signal the evacuations of that corrosive anger within the Ruler's heart. During an undesirable visit by two top security men, Kamïtï wonders whether he should play the angry wizard by (22) "threatening fire and brimstone" (p.372). Likewise, Nyawïra's movements during the visit are likened to 'a hurricane': (23) "Nyawïra would appear with the force of $\boldsymbol{a}$ hurricane and stage so spellbinding a performance" (p.374). Moreover, her phone message to the security men is couched with powerful symbols:

(24) "Those who took you from here must return you here. Should they bring you back with even a single hair missing, they will suffer the full extent of my wrath. My anger is hotter than the hottest zone in hell. Aburiria will tremble with troubles yet unseen. Let them not forget the broken pieces of calabash (p.418).

In addition to the highlighted lexical items, this quote contains 06 strengtheners: 05 modulators and 01 hypersuperlative. The tenor set by these items dovetails with that entailed in this comparison: (25) "Nyawïra was like a firebrand without a handle" (p.318). She thus appears as a hard-liner, a passionate supporter of her chosen side in the power struggle. The use of thunder as a symbol of power comes out clearly in the MVP's debating a plan (26) 'to use the queues so as to steal the Ruler's thunder" (p.199).

An officer equates the WOC to the same signs as the Ruler, as he emphatically states:

(27) Personally I knew that he possessed the ability to change himself into a man or $\boldsymbol{a}$ woman or $\boldsymbol{a}$ child or into anything else. He is a whirlwind. He is lightening. He is thunderstorm. He is the sun and the rain. He is the moon and the stars. How can you draw the likeness of air, breath, soul? The Wizard of the Crow is the being that animated everything and how can you draw a picture of that? (p.569)

(28). While travelling on foot, one day, A.G. saw pasted on an electric post a poster bearing what seemed to be a picture of the WOC...It was not a photograph. It was more like a police sketch. He recalled his talks with Machokali and his warning that no human could draw the likeness of the WOC because he was many things: a man, a woman, a child, a cap on somebody's head, a bird, lightening, a whirlwind! This sketch looked like a cross between Jesus and Sikiokuu, and it offered a prize to the WOC (pp.570-1)

The fact that the WOC cannot be precisely pictured entails that he cannot be iconized (as a human), the fact that he can manifest in natural signs shows that he can only be indexed (as God) but the resemblance between the attempted stretch and 'a cross', symbol of Christ, somehow puts him on equal footing with the Son of God. Thus, not only does he appear as a genderless, an indefinable and un-anthropomorphic character like spiritual creatures (Galatians 3:26, 28; Revelation $21: 9$; John $3: 1,2$ ) but he is also variously referred to in the ways God, or Christ, is: " $a$ Spirit" (John 4: 19-24); " $a$ person, an individual, whose name is Jehovah" (Psalm 83; 18); "the Rock," "the sun”, 'the shield" (Deuteronomy 32: 4; Psalm 84:11), "thunder, brimstone, lightening” (Psalm: 18), 'a consuming fire' (Deuteronomy 4: 24; Hebrews 12: 29), 'a storm, a whirlwind' (Nahum1:3) etc. The Gĩkũyũ God Ngai is also believed to manifest Himself through these media (KPK: 5). While questioning Tajirika about his possible involvement in the subversion against the Ruler, Sikiokuu first resorts to two proverbs with indexes to express his certainty about his suspicion: (29) "Dark clouds herald rain. Where there is smoke, there must be fire" (p.345). Here the 'cloud-rain' and 'smoke-fire' indexical links are at work and strengthened by 'must'. The Ruler has used the same proverbs neutrally to point to the same suspicion: (30) "It is said that there is no smoke without fire. Dark clouds precede a storm" (p.244).

\subsection{Analysis of Faunal Symbols as Expression of Power}

In addition to natural signs, faunal symbolism, through metaphorical identification with animals, is used to express tenor among the characters. The Ruler's association with strong animals and exclusive right to wear clothes patched with skins of mighty cats is the most obvious example of this: 
(31) The Ruler, a staff and a fly whisk in his left hand, stood up. His dark suit was almost identical to that worn by Machokali, but in careful examination one could see the stripes were made of tiny letters that read MIGHT IS RIGHT..... What distinguished his clothes from all imitations by all political fawns were the patches on the shoulders and elbows of his jackets, because they were made from skins of big cats, mainly leopards, tigers, and lions. In short, no politician was allowed to wear clothes with patches from the skins of His Mighty Cats. This special feature had inspired the children to sing how their Lord: Walks the earth like a leopard, / Lights the path like the eyes of a tiger/and roars with a lion's fury" (p.20) (emphasis mine).

The likening of the Ruler to 'the lion', i.e. 'the King of the Jungle' (Ngũgĩ, 1987: 25), 'the leopard', an animal singled out as an all-snatching/grasping or shrewd or brutal tyrant king and 'the tiger', known its quick bouncing on its preys, shows the Ruler as a dictator without compare. The inscription 'MIGHT IS RIGHT' says it all. Thus, MVP's "we oppose the right of might with the might of right" (p.210) becomes a clash between 'dictatorship' and 'democracy. In addition, the Ruler's 'staff/club', known in Swahili as 'a rungu,' symbolises power (Kamau, 2016; KPK, 2013). Tajirika also holds this power-connoting staff and even uses it as a strengthener: (32) "His snugly gloved right hand matched his skin and held a small staff, an imitation of the Ruler, which he pounded in his left for emphasis when he spoke" (p.52). The painting on a bar wall in Matigari shows how animals are used to express tenor:

(33) On the wall were murals of wild animals. An elephant, a hyena, a buffalo, a snake, a leopard and a zebra sat in a circle, all holding a bottle of beer in one hand. King lion sat in the centre of the circle, collecting money. On the crown he wore were the words 'King of the Jungle'. On his belly was the word 'Tribute', and at his feet was a barrel with the words 'Drink it, Drink it, After All, It Costs So Little, Drink It!" (Matigari: 24-5, my emphasis)

Of these seven animals, three, i. e., the lion, the leopard and the snake are found to be associated with the Ruler, which entails various facets of authority and trickery. In addition, the term 'tribute' designates a gift or compulsory payment intended to show gratitude, respect, admiration or dependence to a superior authority. In WOC, the Ruler is shown to get a share of bribes from all contracts:

(34) In his brief tenure as Minister Kaniũrũ had seen the extent of the Ruler's greed. There was no defense contract, even the tiniest, from which the Ruler did not expect a cut. Not that Kaniũrũ was judgemental. He had found out in the same period that all the big merchants of death had bribe money built into the costs of securing lucrative contracts for their companies and their governments. So the Ruler was part of a global corruption in the arms trade (pp.712-13).

Minister Sikiokuu uses the proverb (35) "one does not rush to hit a snake before it has fully come out of its hole" (p.24) to refer to the Nyawïra-chaired MVP and the Ruler amends the proverb (36) "the aging white man feeds on spring chicken" into "a white man renews his youth with spring chicken" (p.6), thus replacing the concept of 'aging' with 'youth renewal' and yet keeping the phase 'a white man'. This shows Ruler's eagerness to identify with 'the white man' but his reluctance to admit to aging. In (34), the 'spring chicken' stands for the 'young girls' he sleeps with in the hope that this would give him longevity and ensure his eternity.

The symbols of 'parrot', 'shepherd' and 'sheep' also help to express power and dictatorship. The change of 'Patriot' into 'Parrot' in the name of a rival newspaper tells a lot on the dictator's attempt to control the press and language, as he proudly says: (37) "In the Eternal Patriot, the underground leaflet he used to edit, he used to denounce me as $\boldsymbol{a}$ creator of a nation of sheep. Now in the Daily Parrot he helps me shepherd the sheep with his literary lashes (p.21). He also draws on the Scriptures (Mark 14: 17; John 10:11,14) to show himself as a good shepherd able to distinguish a liar from a truth-teller: (38) "Mr. Sikiokuu, you know, don't you that a good shepherd knows a hyena when he sees one, even if it is in sheep's clothing?'(p.540). But, while the Ruler sees himself as 'a good shepherd', the ruling elite are seen as 'wolves and hyenas' and the people as 'the shepherds and shepherdesses'

(39) Theft and corruption have become the order of the day. That is what people pride themselves on. Should the shepherd and the shepherdess let the wolves and hyenas herd their sheep for them?" (Matigari: 137-8).

It must be noted that the term 'Parrot' (35) is the English rendering of one of Daniel Arap Moi's nickname 'Nyayo' and his ideology of 'Nyayoism'. In September 1984, Moi, quoted by Ngũgĩ (1986), declared: "I call on all ministers, assistant ministers and every other person to sing like parrots....You ought to sing the song I sing. If I put a full stop, you should also put a full stop. This is how the country will move forward" (p.86). In Matigari, these descriptions a minister, two academics, a newspaper editor, a Provincial commissioner, an MP, and a party chairman, show how deeply-rooted this philosophy is:

(40) "The minister wore a dark suit with grey stripes....the party tie had the emblem of the ruling party -a picture of a parrot -and the letters KKK, the initials of the party" (pp.100-1) 
(41) "They sang three stanzas from the Songs of a Parrot, clinging to the hymn-book as though their lives depended on it" (p.104) ... "they made as if they were about to stand up and sing a few more stanzas from Songs of a Parrot; but the minister, embarrassed by their readiness to sing, asked them to wait for a little while" (p.108).

(42) "He too wore a KKK tie. His colonial uniform seemed to weigh heavily on him" (p.117).

(43) "He wore a silk suit, $\boldsymbol{a}$ KKK tie and thick-rimmed sun-glasses. He greeted the people by singing one or two verses from Songs of a Parrot" (p.119)

(44) "On his shirt were a huge photograph of His Excellency and the party symbol of a

parrot. Below this were the letters KKK. These initials were also on his handkerchief' (p.119)

The picture of the parrot symbolises the Ruler's Nyayoism, which entails speaking in the same voice as the Ruler and thus, absence of contradictions. Though the initials ' $K K K$ ' stand for 'Kiama Kiria Kirathana,' they onomatopoeically evoke the 'Ku Klux Klan,' an extreme white supremacist society, and thus hint to dictatorship or terrorism. Indeed, it is implied in (40-44) that all bodies of the ruling elite (the executive, the legislative, the academic, the administrative, the judiciary and even the religious) adhere to this ideological facet of dictatorship. However, people's rejection of it, signaled by their refusal to attend the seminar on it (WOC: 572), can be felt in their jubilant songs against the ideology in Matigari: (45) "The culture of Parrotry must burn! Yes, the culture of Parrotry must burn!" ...Burn Parrotology burn! Burn Parrotology-burn!" (Matigari: 168; 169). Here, the combination of the strong modulator 'must' with exclamatory and imperative moods testify to what extent Nyayoism is rejected by the mass.

In the quote below, Sikiokuu uses animal symbols to express tenor and encourage bribe collection and trickery, success in which is seen as a symbol of power:

(46) "Sir Titus Tajirika; you will never be anything more than a clumsy collector of bribes. The Waswahili say that if a Muslim must eat pork, then he might as well choose the juiciest. The same with the English. Better be hanged for a sheep than for a lamb. If you must accept bribes, at least have the imagination to ask for more than just a few symbolic, or else keep your nose clean, like John Kaniũrũ your deputy" (p.353, italics in the original, my bolding).

With the 'juiciest pork' and 'sheep-lamb' symbols, Sikiokuu is of the same mindset as the chairman of the Umuofia Progressive Union who blames Obi Okonkwo for being jailed for a 'thin bribe' - "If you want to eat a toad, you should look for a fat and juicy one" (Achebe, 1960: 5). While the 'sheep-lamb' symbol is used to reflect the worth differential between a 'real bribe' and 'a symbolic one', the 'lion-lamb' one (Isaiah 11: 6-9) is used in (47) to refer to the unequal 'employer-employee' tenor:

(47) Has anything like this ever happened before in the history of the world? The lion and the lamb lying together? Fear not those who queue in hope but those who fear those who queue in hope" (p.162).

The burning of the effigies of the 'cursed four' -Machokali, Mambo, Kamïti and Nyawïra'- shows the use of icon for symbolic and ideological purposes. Indeed, the sculptures of those that the State succeeds in eliminating burn but those of those they think dead fail to do so: (48) "The effigies of Nyawïra and the Wizard of the Crow would not burn instead they spat balls of fire that chased those who had tried to burn them (p.720, my emphasis). This failure is a signal that these two figures are still alive and will continue to threaten the security of the ruling elite, as the fire spittle indicates.

In Sikiokuu's address (49): "Kaniũrũ, so it is true what the Waswahili say, that a donkey shows gratitude through its kicks?” (p.535), the 'donkey-master' symbols stand for 'benefactor-beneficiary' to express Kaniũrũ's ungratefulness to the man he has defrauded after the latter has raised him to prominence. The same Bible-inspired adage (Numbers: 22: 28 ) is used by the two officers fired by the Ruler they have 'faithfully/loyally served' on the basis of 'brazen lies': (50) "Yes, a donkey expresses gratitude by its kicks" (p.634). Intriguingly, these two men are twice likened to dogs, an animal reputed for its loyalty:

(51) "But like dogs on a hot trail, the other two police officers kept up the chase as if bewitched and could not say no to their feet" (p.75, my emphasis).

(52) "Stray dogs, even when they have snatched something, are treated more kindly by passersby than we were treated by those we had served faithfully all our lives" (p.633, my emphasis).

Here, the 'stray dog' symbol helps to express the master's ungratefulness to the servant's loyalty, which becomes enhanced to general cruelty of the powerful to the powerless, as Kamïti, after being humiliated from office to office in job search, thinks to himself, identifying himself to a stray-dog: (53) "He had been thrown out of offices like a stray dog” (p. 61). Here, Tajirika, Kamiti's 'heartless interviewer' becomes used as a symbol of cruelty as he and the likes of him are emphatically equated with ogres: (54) "These are really the ogres said to have two mouths, in the front and at the back" (p. 61). The plural 'ogres' entails that Tajirika is used as a symbol of cruelty. Indeed, after a surgery, Tajirika 
ends up as a man 'with a white left leg and a white right arm' (p.741), which gives him, from his twins' point of view, a real appearance of an ogre:

(55) When Gacirũ saw her father naked as she was going to the bathroom to change, she thought she was seeing an ogre and suddenly her mother's transformation acquired a different meaning. She could hardly run to her for protection. Perhaps these ogres have taken over the bodies of their parents as ogres certainly did in stories, except that this was not a story, and her solution was to run away, beckoning to her brother to follow, no questions asked (p.742).

Though the processes 'saw,' 'thought', and 'was seeing' point to the subjective nature of the vision, as the weakener 'perhaps' shows, but the plural 'these ogres' generalize the 'ogre stigma' to the Tajirikas and the whole ruling elite, which is stressed by 'certainly' and the repetition of the 'these armed ogres' (p.759), 'these ogres' (p. 759), 'the current program of these ogres' (760). It worth recalling that the deictic "this/these" can play a situational reference function, an anaphoric reference function and an interpersonal function in which it indicates the attitude of the speaker to the thing or person being spoken about (Amoussou, 2015a). In this context, the phrase 'these ogres' shows the speakers' negative judgement or tone of disgust or scorn for the new elite, spearheaded by Tajirika (Fowler, 1986; Eggins, 2004). Earlier, the very children have likened their father, for his incessant utterance of the 'if-word', to a dog: (56) "The children said that they did not want to stay home with their father because he kept on barking a single phrase over and over, and they were a little afraid that he might be turning into a dog" (p.153).

When Kaniũrũ visits Nyawïra's father offering to acquire shares in his ailing companies in exchange for information about his daughter's whereabouts, he uses two proverbs and a tale with animal symbols to pressurize the old man into instant decision $(57,58)$, to which the old man replies with the true version of the same tale (59) to mean that too much haste would make no champion:

(57) "Let us dance around each other like two bulls in a kraal” (p.289).

(58) "As the saying goes, the one in need is the one who presses his needs. Let me remind you: don't be as slow as the tortoise in the story...."

(59) "Wangahũ himself felt like reminding Kaniũrũ that it was the slow tortoise who won the race, not the hasty hare, but he held himself back (p.287)

The same 'bull' symbol(57) is used by Sikiokuu while interrogating Tajirika to deny the captive equal status (60), even though Tajirika sees himself as 'a bull in the kraal' (61), thus having the same status as Sikiokuu:

(60) "Look, Tajirika, let's not be like two bulls circling each other, reluctant to engage. Here I am the only bull in the kraal. So stop skirting the issue. Go to the point" (pp.398-9).

(61) "He was not about to cede that right to another bull in the kraal" (p.426)

The State newspaper even uses the Hare-Tortoise race $(58,59)$ to promote a project:

(62) America, take notice that we will not let you monopolize Space. We are right behind. We might be several years behind in science and technology, but we shall surely win the race like the Tortoise in the story, who defeated the Hare (p. 23).

In a meeting, Tajirika mentally uses a proverb with animal symbols to ignore Sikiokuu's 'evil eye' telling him not to reveal critical information: (63) "Tajirika saw the evil look of Sikiokuu, but he knew that the eyes of a frog in a brook do not prevent cows from drinking water" (p.529, my emphasis). Here, the tenor between ' $a$ cow' and 'a frog' is drawn on to express Tajirika's one with Sikiokuu who is seen as 'a frog' while Tajirika sees himself as ' $a$ cow'. A similar symbol is used to the same effect in (64): "A little fear crept into his certainty. Sikiokuu was now in charge of the country; and as the Waswahili say, Paka akinenda panya hutawala. Might he not be devoured by the rat that now ruled in the absence of the cat?" (p. 299). Here, 'the rat' stands for Sikiokuu, 'the cat' for the Ruler and, by inference, 'the fish' for Tajirika. The same 'cat-mouse' symbol helps to show the power relation of the Ruler to Machokali: (65) "He was confident about what he had up his sleeve and was waiting for the right moment to pounce, so he just sat quietly, like a cat awaiting its prey, allowing Machokali to continue without interruption" (p.238; emphasis added). During his captivity, Kamïti uses the very symbol to describe his weak position to the Ruler: (66) "He introduced Kamïti to Tajirika, and Tajirika smiled as if encountering an old friend. Their jovialness convinced Kamitï that they were playing a cat and mouse game with him regarding Nyawïra" (p.600; emphasis added). It is even implied that Kaniũrũ's lower status prevents him from voicing his disagreement with higher-standing characters like Sikiokuu who is likened to a chameleon, an animal known for its flexibility: (67) "Kaniũrũ was not exactly pleased to hear that Tajirika occupied a significant place in Sikiokuu's scheme of things. Why is this minister changing like a chameleon? Was he about to dump him despite his loyal service? He fumed: he had no way of voicing how angry he was with Sikiokuu, Tajirika and Vinjinia" (p.460, my emphasis). The same symbol is used by the Ruler not only to point to the fluctuations of the national currency, but also to Tajirika's flexibility and bright insight as an adviser, an asset that helps the latter to ensure 
his survival and draw the Ruler's admiration and praise: (68) "He, too, thought the national currency worthless, its value always changing like a chameleon. He now saw Tajirika in a new light: here was a bright mind that knew how to make a dollar out of thin air" (p.538). A case of vocalized instruction become insomniac for Sikiokuu is the Ruler's demand to have Nyawïra detained before his return from America:

(69) Like a mosquito in the dark, the Ruler's unequivocal order that by the time he came back from America he should find Nyawïra in custody, kept z-zinging in Sikiokuu's ear. Nyawïra's capture had always been a priority, but now, after the call, the z-zinging intensified: she must be taken to custody" (p.341).

The strengtheners 'should' and 'must' signal the urgency for the minister to catch Nyawïra and the Ruler's order in English symbolises 'death sentence' as Sikiokuu thinks to himself:

(70) "The Ruler had warned him in English, and Sikiokuu had been in Aburirian politics long enough to know that this amounted to a death sentence" (p.218).

In these quotes, Sikiokuu is likened to 03 animals -a rabbit, a hippo, a dog:

(71) "His ears were larger than a rabbit's and always primed to detect danger at any time and

from any direction (p. 14).

(72) “As he left the State House, Sikiokuu fumed, and some even say that, like a hippo's under water, his heavy breathing produced bubbles of air from his mouth and nostrils and that the bubbles surrounded him and his car all the way to the office" (p.164)

(73) "Sikiokuu immediately threw it to the floor and started stamping it, his ears flapping rhythmically. By the time he finished, the mirror shattered into tiny bits, he was panting like a hippo, his nose sweating like a dog's (p. 416).

When he is lied to by Sikiokuu that Machokali, his most loyal minister, has a link with the MVP, the Ruler's greets the latter with a Swahili proverb (74) 'Kikulacho kimo nguoni mwako: the bug that bites one's back is carried in what one wears $($ p.190, 521), to hint to betrayal by a close partner. This adage is earlier used by Tajirika to entail his possible bewitchment by his deputy to snatch his position (p.190). After being humiliated by Tajirika in a job interview, Kamiti later tells him: (75) "Need, like love, is blind! A tired bird in flight will land on anything" (p.385); taking himself as 'a tired bird' and Tajirika as 'anything/a rot', as he is one of most rotten figure in the novel (Amoussou, 2015 b: 225-6). In addition, the need-love comparison somehow helps Kamitï to air his disappointment with Wariara, i.e., his first love turned a whore. A similar proverb is used by Machokali when he has no other choice than to call upon a sorcerer to heal the Ruler's malady of words and SID in New York: (76) "Machokali did not much believe in witchcraft and divination. But $\boldsymbol{a}$ bird exhausted in flight lands on the nearest anything, and for him the Wizard of the Crow was now that anything" (p.477). It must be noted that the item 'any tree' in the original adage (Ngũgĩ, 1982: 33) is replaced by 'anything' in (70) and (71) to reinforce to the hostile tenor of the comparer to the compared. The miraculous flight of the seemingly disabled beggars is put into 'birds-of-a-feather' imagery to express the move from solidarity to individualism: (77) "Birds of a feather flock together in times of trouble, but when there is danger, each flies alone" (p.75).

In this mental process, the captive Tajirika sees himself as ' $a$ sheep' before 'a shearer', just as in the scriptural prophecy about Christ's crucifixion (Isaiah 53: 7-8; Acts 8:32):

(78) These two policemen must really hate me, Tajirika said to himself. I'm sure I shall not leave this place alive. But instead of despairing, he bolstered his sagging energy by recalling the saying that even an animal about to be slaughtered tries to kick those leading it to the slaughterhouse (p.553).

His determination to struggle entails his rejection of passive acceptance of fate, and puts him and his 'captors' on the same wavelength respectively with 'the tortoise' and the leopard' in the story of a Tortoise about to die (Achebe 1978: 128). A similar 'hunter-wounded animal' symbol is used to point to Machokali's desperate need for self-defence in face of the serious charges against him: (79) "Machokali knew without a doubt that he was in big trouble. But he would at least go down defending himself, like a wounded animal" (pp.239-40). The same symbols (74, 75) are used by the WOC to solace his need to defend himself: (80) "If the dictator intended to kill him, he would do it anyway, no matter what the Wizard of the Crow said. Even an animal taken to the slaughterhouse offers resistance, the wizard said to himself' (p.668). Finally, Tajirika uses both an animal and a social symbol to describe his political ascension which he sees as a (81) "dramatic rise from a jailbird to gold digger to governor to Minister ...." (p.741). After his torture, Tajirika sees himself as being less worthy than 'a donkey' - (82) "Even the donkeys of Santamaria market are treated with less cruelty" (p.335), but on uttering his desired European names, he is also seen as being (83) "as proud as a peacock" (p.182). The Ruler also resorts to an adage with an animal symbol to refute Sikiokuu's suggestion that Tajirika be removed from office for the suspicions against him: (84) "we do not change horses in midstream" (p.244). Sikiokuu is likened to a sycophant or toady: (85) "Sikiokuu used to kneel before the Ruler, but it was more a 
sycophantic gesture than an act that came from the heart" (p.671). The term 'sycophant', or its related term 'toady', refers to either a servile flatterer or a stout-bodied fish that inflates itself like a balloon when threatened. Both meanings apply to Sikiokuu as a manipulator and a bully, the toady's stout build reinforcing the comparison with a hippo (72, 73). Intriguingly, the man's sobbing creates, though not an earthquake like the Ruler's (18, 19, and 20), a car-quake:

(86) Resting his head on folded arms on the steering wheel, Sikiokuu, the Ex-Minister of State in the Ruler's Office began to weep. His heaving made the car shake, and he came back to himself only when the car started honking and he realized that he had pressed the horn in error" (p.685, emphasis added).

Floral symbolism is also at work to prohibit multiparty. For instance the 'Carrot-Stick-Sweetness' policy is at the heart of the Ruler's control of the opposition: (87) "Above-ground, the Ruler proved adept at stifling all other nascent opposition through the carrot and the stick. He gave the carrot to the elite of the various ethnic communities and the stick to all signs of defiance. But sweetness was reserved for the armed forces" (p.234, my emphasis). Here, the term 'carrot' symbolises anything enticing offered to a person as a means of persuasion, 'stick', 'punishment/repression', and 'sweetness', 'generous favour' given to the army to secure their loyalty. Indeed, the 'stick' is used when the 'carrot' and 'sweetness' fail. The Ruler is here mentally praised for his effective use of this policy:

(88) "The Ruler is truly gifted with the carrot and the stick, Sikiokuu said to himself, grateful that he had not been fired from his ministry and had retained one of his loyalists, Njoya. But still, he smarted at the thought that Kaniũrũ had been promoted a given a subdivision to head" (p.559).

His ability to break women into submission through this policy is also praised in this Machokali-sensed mental process: (89) "Machokali never ceased to marvel at the Ruler's way with women, especially this woman, who stopped being a follower of Mao Tse-Tung to become a faithful lapdog of the Ruler" (p.509). The phrase 'a faithful lapdog' says it all about the relationship between the deputy ambassador and the Ruler; and the plural form 'women' 'makes' her a typical/symbolic character. However, the strategy squarely fails with Nyawïra's MVP, which is why the Ruler resorts to the 'fisherman-worm-fish' symbols to justify his use of 'stick' to repress the recalcitrant women and their like-minded: (90) "A fisherman puts a worm at the end of the line; but if the fish ignores it, how is the fisherman to catch the fish?" (p. 235). As a result, he instructs Kaniũrũ to have (91) "the leaders of rebellious youth and women...crushed like ants" (p.558). The same 'fish symbol' is used to refer to Nyawïra, who is seen as a bigger threat to the Ruler than any other: (92) "The torturers were after $\boldsymbol{a}$ bigger fish: they wanted a word, a gesture, that would lead them to Nyawira" (p.269)

The Ambassador Gemstone uses 'a monkey-trickster' symbol, seeing the people as 'monkeys', to the Ruler's agreement, to address the need for the Ruler to appease them with a trick: (93) "Don't you have a proverb that says that if you throw peanuts to a monkey you will distract it long enough to be able to snatch its baby?" (p.641). The Ruler also sees Kamïti as 'a pig', as is clearly entailed in the use of a human-endowed pronoun 'his': (94) "Having incorporated the powers of the wizard into himself, the Ruler would have him thrown into a dungeon, fry the pig with his own fat" (p.561). It must be reminded that the item 'pig' interpersonally refers to a greedy/dirty/unpleasant/undesirable person and suitably expresses the tenor between the Ruler and the Wizard. The same adage is used by Tajirika, with the insinuation that his white-ache can be used against itself for a cure: (95) "Have you not heard the saying that $\boldsymbol{a}$ pig is fried in its own fat?" (p.181). Likewise, Jane Kanyori, through Kaniũrũ as a symbol, treats all the men as 'chauvinist black pigs': (96) "Has the defense portfolio turned you into a male chauvinist black pig? And here I thought that you were a liberated Aburirian male?" (p.711, italics in the original). Interestingly, the pluralisation 'the beastly and meanspirited Kaniũrüs of Aburiria" (p. 632) confirms the use of Kaniũrũ to symbolise women-denigrating men. The RulerThorn clash in (97) turns out to be a personified version of the 'Elephant-Thorn' story told Machokali by A.G. (98) to mean that the strong should not overlook the weak, as in that story, the small thorn causes the elephant to die, just as the small ant does in a similar tale:

(97) "These revelations made the Ruler wince, like a person who starts walking confidently along a path he believes to be clear of all obstacles only to suddenly step on a thorn" (p.542).

(98) Elephant felt something sharp in his foot, and when he removed it and saw that it was a tiny thorn, he was very angry. How can such $\boldsymbol{a}$ tiny thing prevent $\boldsymbol{a}$ big animal like me from walking? He pushed the thorn back into his foot and walked on, stamping on the ground in defiance. The infection that later developed killed the elephant. Hence the saying 'Never look down upon the small' (pp.473-74).

This story somehow brings to the tour de force in the interpersonal use of the faunal-floral symbols as this 'Elephant' vs. 'thorn' symbolic duo helps to express four power relationships - 'the Ruler' vs. 'the WOC'; 'Machokali' vs. 'the WOC'; 'Machokali' vs. 'A.G. and 'the WOC'vs. 'A.G.'-, with 'Elephant' standing for the first item and 'the thorn' for the second. Indeed, the Mighty Ruler urgently needs healing from the low-status sorcerer, the powerful minister is obliged to rely on the law-status policeman to identify a sorcerer, and he is to cooperate with the low-status wizard in the process. What is more, the detective sees himself as 'a messenger' of the wizard, placing himself below the latter. Finally, this symbolic duo expresses the tenor between Western doctors and African healers, as the wizard succeeds where the others utterly fail, to their fury and discontent. 
Table $_{2}$ recapitulates and categorizes the major findings of the first analytical section.

Table 2. Recapitulation of Findings of section 3.1

\begin{tabular}{|c|c|c|c|c|}
\hline $\begin{array}{l}\text { Quote } \\
\text { nos }^{\text {os }}\end{array}$ & signifier & signified & Sign mode & function \\
\hline 1,2 & earth tremor & the Ruler/Satan & index & satanization \\
\hline $3,4,5,6$ & whirlwind & the Ruler/Satan/Snake & Index, symbol & satanization \\
\hline \multirow[t]{2}{*}{7,8} & Pharaoh, Snake & the Ruler & symbol & dictatorship \\
\hline & Moses & MVP & symbol & democracy \\
\hline 9 & the Magi, Herod & Soldiers, the Ruler & symbol & dictatorship \\
\hline 10,11 & wind & threat & index & insecurity \\
\hline \multirow[t]{2}{*}{11} & Sun & oppression/greed & index & power to dispossess \\
\hline & Businessman & greed & symbol & character type: hypocrisy \\
\hline 14 & Priest & Church & symbol & character type: hypocrisy \\
\hline $\begin{array}{l}14,16 \\
17\end{array}$ & Sun & The Ruler & symbol & power/modulation \\
\hline $\begin{array}{l}18,19 \\
20,21\end{array}$ & $\begin{array}{l}\text { Thunder; earthquake, ire, } \\
\text { fire etc }\end{array}$ & $\begin{array}{l}\text { The Ruler's plane, his } \\
\text { shaking hand, anger }\end{array}$ & index & $\operatorname{mood}$ \\
\hline 22 & Fire, brimstone & Wizard's anger & index & threat \\
\hline $\begin{array}{l}23,24, \\
25\end{array}$ & Nyawïra's actions & $\begin{array}{l}\text { hurricane, earthquake, } \\
\text { firebrand }\end{array}$ & index & anger/wrath/mood \\
\hline 26 & Thunder & Ruler's power & index & dictatorship \\
\hline 27,28 & $\begin{array}{l}\text { whirlwind, lightening, } \\
\text { thunderstorm, the sun, the } \\
\text { rain, the moon, etc }\end{array}$ & Kamiti's attributes & Index/symbol & $\begin{array}{l}\text { Kamiti's spiritual } \\
\text { endowment }\end{array}$ \\
\hline \multirow[t]{2}{*}{29,30} & Clouds/dark clouds & rain/storm & index & certainty \\
\hline & smoke & Fire & index & certainty \\
\hline
\end{tabular}

As can be seen, the Ruler is semiotically (indexically or symbolically) likened to Satan $(1,2,3,4,5,6,8)$; to supernatural signs $(1,3,11,13-20,26)$ and to two dictators -the Pharaoh and King Herod (7, 9). Indeed, the Ruler is proven, despite his efforts to show his Christianity, to be 'a Devil Worshipper', and is rejected by religious leaders as 'an incarnation of the Prince of Darkness' (p. 247). This clash between the personal and interpersonal views of the Ruler finds a parallel with those of the then Kenyan President Moi: "Every Sunday, the man is photographed clutching to a Bible in church" (p.2) to show his religiosity but he is seen as "an angel in public, a demon in private" (Njuru, 2016: 2).

To convey this unfriendly message, the narrator has not only borrowed the characters' focalisation and voice, but has also resorted to modalisation -with 11 modality metaphors $(1,2,18,19,20,30)$ and 14 modalisers in $(1,3,6,8,9,15$, 25,28 ). It must be emphasised that the modality metaphor functions to help speakers to variously express their opinions but more usually to disseminate the fact that they are expressing their own opinions (Halliday \& Matthiessen, 2004) while the modalisers or weakeners function to signal the narrator's subjective speculation on the events (Fowler, 1986; Amoussou, 2015a). On the other hand, 20 modulators/strengtheners are resorted to emphasise the power expressed by supernatural symbols or coveted by characters: 01 (2), 02 (7), 01 (8), 02 (12), 02 (16), 01 (17), 02 (18), 01 (21), 06 (24), 01 (27), 01(29). Direct metaphor is also at work to equate characters to symbols that have no link with humans, such as the cases marked 'symbol' in table 2 . Kamiti is equated to 10 supernatural powers, introduced by the strong modal operator (27). This metaphorical use creates a brusque link between the signifier and the signified and justifies the mystery around the WOC, who is described like both God and Christ (Matthew 9: 6-7; 9: 29, 33; Luke 5: 24-25; 8: 52-56; 13: 12-13), as 'the being that animates all things'( p. 571)

In section 3.2, about 70 discourse strings are identified in which animals are used to express tenor among characters. In addition to being likened to a snake $(6,7,8)$, the Ruler is so, directly or not, to $\mathbf{1 8}$ animals: 'a lion', 'a tiger', 'a leopard' $(31,33)$, 'a shepherd' $(37,38)$, 'a wolf' and 'a hyena' (39), 'a donkey' (50), 'a cat' (64, 65, 66), 'a host' (74), 'a mosquito' (69), 'a parrot' (40-44), 'a fisherman' (90), 'a monkey-trickster (93), 'an elephant' (97-98), 'a white man' (36) and 'a terrorist' (40-44), a 'shearer/slaughterer' $(78,79)$. The other people are petted against him with weaker symbols like 'spring chicken' (36), 'a sheep' (37, 38), 'a hyena' (38), 'a bug' (74), 'a fish'(90, 92), 'rat' (64), 'a mouse' (66) 'a monkey’ (93), 'a prey’ (65), ‘a pig (90‘), ‘a dog/stray dog/lapdog' (51-53; 89), 'ants' (91) ‘a thorn’ (97-8), etc. 
An animal index is even used for the Ruler-sent planes to chase the enemies: (99) "The helicopters like hawks hovered to swoop on the fugitives" (p.217). Finally, his staff or 'rungu' (31) is a symbol of excessive power: "The rungu would be an apt symbol for Moi's rule. There is no problem Moi could not solve using violence or the threat of violence. Rather than cultivate respect, he rode power through sheer fear" (Njuru, 2016:8). The same applies to Tajirika for his 'rungu' (32) and ogre-stigma (54, 55).

Tajirika is likened to 14 animals: 'an ogre' (54-5), 'a dog' (56), 'a bull' (61), 'a cow' (63), 'a fish' (64), 'a cat' (66), 'a chameleon' (68) 'a host'(74), 'any treela rot' (75), 'a sheep' (78), 'a jailbird' (81), 'a peacock' (82), 'a donkey' (82), and 'a horse' (84). Sikiokuu is symbolized by 10 animals: 'a hyena' (38), 'a donkey-master' (49), 'a bull' (60), 'a frog' (63), 'a rat' (64), 'a chameleon' (67), 'a rabbit' (71), 'a hippo' (72, 73), 'a dog' (73), and 'a toady' (85). While the rabbit-tag reflects his enlarged ears to serve the Ruler (p.18), the dog one stresses his loyalty to him. As the rat comparison, it shows his inferior status to the Ruler while the hippo and toady ones do his strong physical build. The 'rider-donkey' symbol also reflects his superior status to Kaniũrũ, just as the 'cow-frog' one does his lower status to Tajirika. As for the chameleon one, it indicates the side-shifting among the key ministers depending on their relative power in a given context. In addition, this animal stands for someone who does not keep their promises; a Gikuyu legend has it that God sent this animal to deliver a message to the people, which it never did (Ngũgĩ, 1982:154).

Indeed, relative tenor between characters is shown through symbolic duos: 'a lion vs. a lamb'= 'an employer vs. an employee'; 'a sheep vs. 'a lamb'= 'a big bribe' vs. 'a small bribe', 'a tired bird vs. anything/a rot' = 'Kamïtï vs. Tajirika'; 'a tired bird vs. 'anything/any tree' = 'Machokali vs. Kamïti’'; 'a sheep vs. shearers' ='Tajirika vs. security men'; 'a sheep vs. a shearer'= 'Kamïï vs. Ruler'; 'a mouse' vs. 'a cat'='Kamïti vs. the Ruler'; 'a cat vs. its prey' = 'the Ruler vs. Machokali’, etc. There also are symbolic trios: 'cat-mouse-fish’='The Ruler-Sikiokuu-Tajirika' (64); 'carrotstick-sweetness'='enticement-repression-generosity' (87); 'fisherman-worm-fish' = 'the Ruler-enticement-MVP' (90), and 'trickster-monkey-its baby' = 'The Ruler-people-democracy' (93).

The fact that the signs are couched in proverbial sentences and folktales strengthened by biblical and local adages immeasurably contributes to the tenor of discourse $(7,11,14,15,16,17,21,29,30,38,46,47,49,50,55,57,58,59$, $60,61,62,63,64,65,66,67,70,74,75,76,77,78,79,80,82,83,84,85,90,93,94,95,97,98,100)$. Fowler (1986: 137) contends that the profuse use of such sentences "makes the reader bound to suspect the objectivity of someone who is so self-conscious, so confident and considered in his judgements (p.137). There is only one modality metaphor (72) but are as many as $\mathbf{3 0}$ modalisers $(31,41,42,46,51,52,55,56,57,58,60,62,64,65,66,67,68,69,72,73,83,97,99$, 100), most of which indicate an indexical link between the signifier and the signified (Chandler, 2001:11-12). The significant proportion of strengtheners, about 29 (31, 45, 46, 48, 54, 55, 62, 63, 69, 78, 94 and 97'made...wince', 101) add to the strong and confident tenor set by proverbial discourse. It must be noted some of the strengtheners $(45,48)$ express people's rejection of the Ruler's rule with such determination that scares or weakens him (97). Plus, the failure to capture his star enemies so much dis-empowers the Ruler that he feels (100) 'like a cornered, toothless animal" (p.639). Indeed, the Ruler, rather than his archenemies, ends up as 'a pig fried in his own fart'. The 'four masked spirits' who destroy him are nobody but the 'four riders' he has initially sent to the four corners of the country to spread his popularity. The coup by these 'four horsemen of the Apocalypse' (Revelation 6: 1-8) symbolises a doomsday for the dictator's rule. The 'Four Spirits' can also stand for 'the voice of the Almighty' (Ezekiel 1: 24) and 'the glory of God' (Ezekiel 1: 26-28), which entails the victory of the Heavenly Lord over the earthly one. That is what the spirits tell viewers after the plot:

(101) The four spirits calmly said that they had been sent by the dead, the living and the unborn to tell the nation that the Ruler and the special hostess Yunique Immaculate McKenzie, had been recalled by the ancestors that very morning. The people should not heed any rumors of a coup.........In fact, the Ruler must have known that his time to go had come, because a few weeks before, he had ceded all his powers to new ruler of Aburiria, Emperor Titus Flavius Vespasianus Whitehead (p.753).

This interpretation is solaced by the fact that the Ruler-employed repressors and torturers, namely John Kaniũrũ, Elijah Njoya and Peter Kahiga, are destroyed by the same spirits: "the four masked spirits were waiting for them at the same riverside. They joined the Ruler in the belly of the crocodiles of the Red River..." (p.755). It turns out all those who abuse power and seek vengeance end up being destroyed by the weapons that they have used to eliminate their victims, which justifies Christ's warning to Simon Peter that 'all who take/draw the sword shall perish by the sword' (Matthew 26: 52) or the Almighty's warning “Vengeance is mine' (Romans: 12:19).

Overall, the 101 discourse strings analysed contains about 103 instances of the three modes of signs, a figure slightly higher because some quotes contain more than one mode or a blend of them (28, 3173 , etc). Drawing criteria proposed in table $e_{1}$, and other specifics along the analysis, the modes are counted and summed up in table below: 


\begin{tabular}{|c|c|c|}
\hline Sign modes & Quote $\mathrm{N}^{0 \mathrm{~s}}$ (signaling device) & $\begin{array}{l}\text { Quantity } \\
(\%)\end{array}$ \\
\hline Symbolic: metaphor & $\begin{array}{l}4,7,8,12,13,31,32,35,36,38,39,40,41,42,42,43,44,46,47,48 ; 49,52, \\
54,55,59,61,63,64,66,70,74,77,78,80,81,82,84,87,88,89,90,92,93, \\
94,95,96,98,101\end{array}$ & $48(46.60 \%)$ \\
\hline iconic: simile, & $\begin{array}{l}\text { 5(-), } 9 \text { (like), } 15 \text { (as), } 21 \text { (than), } 25 \text { (like), } 28 \text { (seemed, like, like, 31, 37( as), } 51 \\
\text { (like), 53(like), } 57 \text { (like), } 58 \text { (as), } 60 \text { (like), } 62 \text { (like), 65( like), } 67 \text { (like), } 68 \\
\text { (like), 69(like), } 71 \text { (than), } 72 \text { (like), } 73 \text { (like, like), } 79 \text { (like); } 83 \text { (like), } 85 \\
\text { (than), } 91 \text { (like), } 97 \text { (like), } 99 \text { (like), } 100 \text { (like), }\end{array}$ & $\begin{array}{l}31 \\
(30.10 \%)\end{array}$ \\
\hline $\begin{array}{l}\text { Indexical: causality, } \\
\text { evocation, modality }\end{array}$ & $\begin{array}{l}1,2,3,6,10,11,14,16,17,18,19,20,22,23,24,26,27,29,30,56,75,76, \\
78,86 .\end{array}$ & $\begin{array}{l}24 \\
(23.30 \%)\end{array}$ \\
\hline
\end{tabular}

The symbolic mode, through the use of metaphor, is found to rate highest $\mathbf{( 4 6 . 6 0 \% ) , ~ f o l l o w e d ~ b y ~ t h e ~ i c o n i c ~ o n e ~ t h r o u g h ~}$ simile (30. 10\%), with the indexical one ranking lowest (23. 30\%). While symbolism creates a direct equation between the signifier and signified, iconicity creates a relationship of similitude between the two. As for indexicality, its major characteristics are causality, evocation and modality, as the modality-markers in the quotes of its occurrence show. The study thus confirms the major characteristics of the symbol, the icon and the index as theorised by semioticians like (Grayson, 1998: 36; Hodge \& Kress, 1988:127; Chandler, 2001: 12) while specifying that context must be heavily drawn upon before deciding to which mode a sign actually belongs (Peirce, 1958: 172, Culler, 1975: 17; Hawkes, 1977: 129).

This study also reveals as much about the sources of Ngũgĩ's political characters as about the power struggle among them. The coincidence between the fictional Washington trip $(18,19,20)$ with a Moi's real one (Kamau, 2012; Njuru, 2016) means that Dr. Machokali, Sikiokuu and Tajirika are respectively portrayed after Dr. John Robert Ouko - Moi's Foreign Affairs Minister who got killed just after the trip, Nicholas Biwott - Moi's nephew and Minister of State and archenemy of Ouko, and Mwai Kibaki - Moi's Adviser and Vice-President (1978-2002) (Kamau, 2012; Njuru, 2016). Just as Sikiokuu is proven as one the most influential Ministers in the Ruler's Cabinet, Biwott was one in Moi's Government (Kamau, 2012; Njuru, 2016). And just as Tajirika's flexibility helps him remain with the Ruler to the end, so did Kibaki's one enable him to serve through Moi's rule.

Indeed, the number and power of the symbols associated with Tajirika and Sikiokuu make them respectively second and third-most powerful figures in the Ruler's Cabinet, after the Ruler. Though strong symbols show Sikiokuu as a physically and political strong figure, Tajirika's flexibility and position as 'a clever adviser' add to the strong symbols to help him outwit the Ruler and become the next President. However, the pendulum of power weighs down on the side of the people or God, as the elimination of the Ruler and his entourage by the symbolic horsemen of the Apocalypse shows. It can thus be forcefully contented that there is hardly any other prose by Ngũgĩ in which human relationship is so vividly revealed through semiotics as in the Wizard of the Crow.

\section{References}

Achebe, Ch. (1960). No Longer at Ease. London: Heinemann Educational Books.

Achebe, Ch. (1978). Anthills of the Savannah. London: Heinemann Frontline Series.

Amoussou, C. Y. (2015a). 'Cognitive Characterisation and Tenor of Discourse in Ngũgĩ's Wizard of the Crow' in PARTIC'ACTION: Lomé: Togo. Vol. 7 No 2. pp. 205- 228

Amoussou, C. Y. (2011). "Characterisation, Focalisation and Discourse in Ngũgĩ wa Thiong’o's Novels: A Functional Structuralist Approach.' Unpublished Ph. D-Dissertation, UAC.

Chandler, D. (2001). Semiotics: The Basics. London: Routledge.

Culler, J. (1975). Structuralist Poetics: Structuralism, Linguistics and the Study of Literature. London: Routledge \& Kegan Paul.

Eco, U. (1976). A Theory of Semiotics. London: Macmillan.

Eggins, S. (2004): An Introduction to Systemic-Functional Linguistics. London: Pinter Publishers Ltd.

Fairclough, N. (2003). Analysing Discourse: Textual Analysis for Social Research. London: Routledge.

Fairclough, N. (2014). Language and Power. London: Routledge.

Fowler, R. (1986). Linguistic Criticism. Oxford: Oxford University Press.

Grayson, K. (1998). 'The Icons of Consumer Research: Using Signs to Represent Consumers' Reality,' in Stern, B. (1998). Representing Consumers: Voices, Views and Visions. London: Routledge; pp.27-43.

Halliday, M. A. K. \& Matthiessen, C.M.I.M (2004). An Introduction to Functional Grammar (3rd edition). London: Hodder Headline Group. 
Hawkes, T. (1972). Metaphor. London: Methuen.

Hawkes, T. (1977). Structuralism and Semiotics. London: Routledge.

Hodge, R. \& Kress, G. (1988). Social Semiotics. Cambridge: Polity.

Kamau, M. M. (July 29, 2012). 'Robert Ouko Was Killed In "Operation Bikini Succession: Weekly Topic Newspaper of Uganda 6 Sept. 1991,' African News Online; July 12, 2012.

Koussouhon, A. L. \& Amoussou, C. Y. (2015b). 'Characterisation, Authority and Ideology in Ngũgĩ's Devil on the Cross,' The Mediterranean Journal of Social Sciences, ISSN 039-2117 (online)/ 2039-9349 (print), Rome, Italy, Vol. 6, $\mathrm{n}^{\circ} 4 \mathrm{p}$ 279-289

Langer, S. K. (1951). Philosophy in New Key: A Study of the Symbolism of Reason, Rite and Art. New York: Mentor.

Leach, E. (1970). Lévi-Strauss (Fontana Modern Masters). London: Fontana.

Morris, Ch. (1970). Foundations of the Theory of Signs. Chicago: Chicago UP.

Ndïgïrïgï, G. (2015). 'Character Names and Types in Ngũgĩ wa Thiong'o's Devil on the Cross and Wizard of the Crow, in Ufahamu: A Journal of African Studies. University of Tennessee, USA, 38 (3), pp. 189-216.

Ngũgĩ wa Th. (1977). Petals of Blood. London, Bedford, Ibadan, Nairobi: H.E.B. Ltd.

Ngũgĩ wa Th. (1982). Devil on the Cross. Heinemann: African Writers Series.

Ngũgĩ Wa Th. (1986). Decolonizing the Mind: The Politics of Language in African Literature. London: Currey.

Ngũgĩ wa Th. (1987). Matigari. Heinemann: African Writers Series. Ngũgĩ wa Th. (2006). Wizard of the Crow. London: Vintage Books.

Njuru, P.K. (January 25, 2016). 'Did President Moi Want Robert Ouko Dead?', http.Rasqoh.com, date consulted: March 20, 2016.

Peirce, Ch. S. (1958). Collected Writings (8Vols) (eds. Hartshorne, Ch., Weiss, P. \& Burks, A. W.). Cambridge, MA: Harvard University Press.

Saussure, F. (1983). Course in General Linguistics. (Tr. R. Harris), London: Duckworth.

Sless, D. (1986). In Search of Semiotics. London: Heinemann.

Sturrock, J. (1986). Structuralism. London: Paladin.

KPK: the Kikuyu People of Kenya (October 21, 2013); Wikipedia; http://orvillejenkins.com/ profiles/kikuyu.html, consulted July 10, 2015.

The New English Bible (1970). Oxford, Cambridge: Cambridge University Press. 